\title{
$\frac{2}{2}$
}

\section{IMPERIUM OF THE SOUL}

The political and aesthetic imagination of Edwardian imperialists

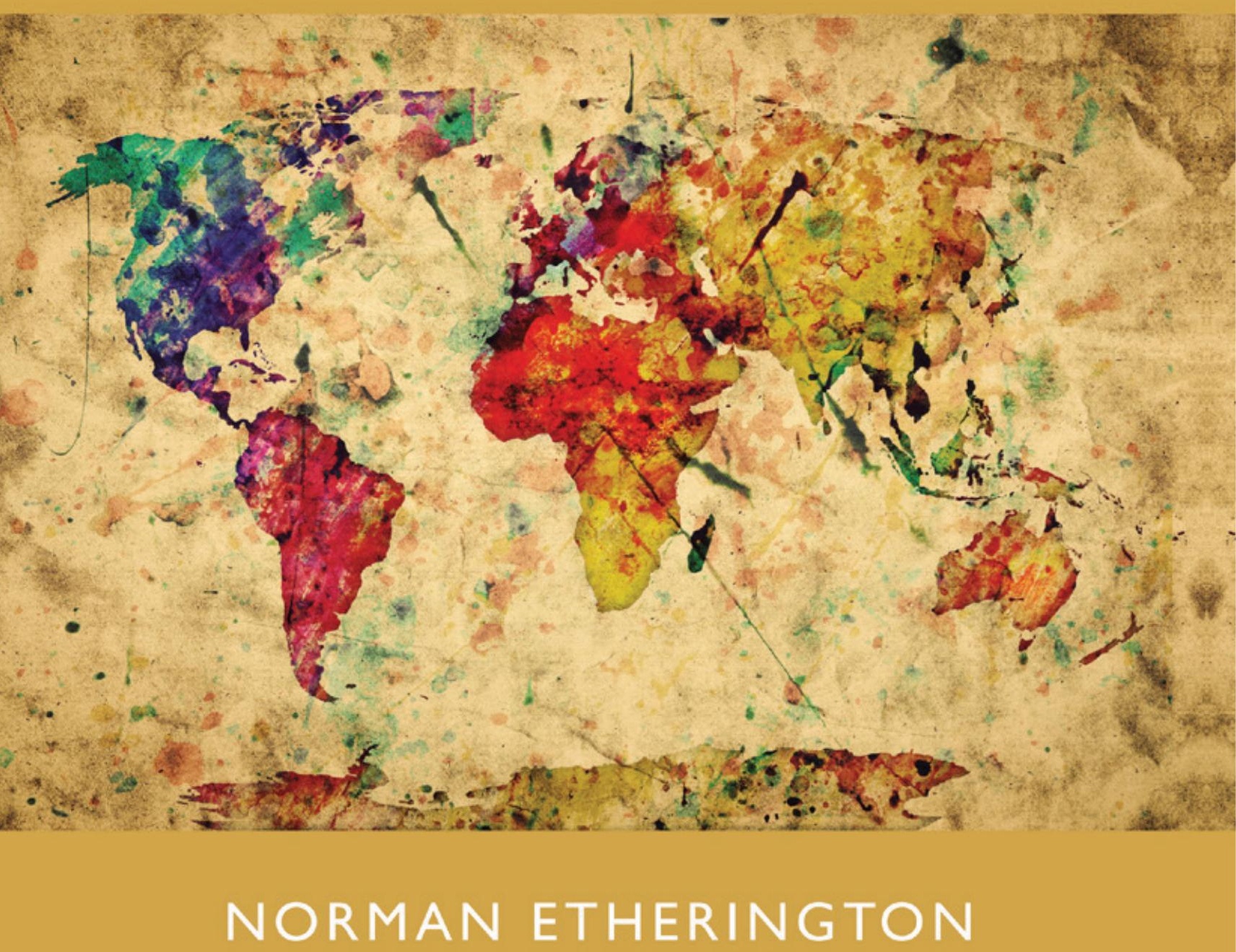




\section{\begin{tabular}{l} 
STUDIES IN- \\
IMPERIALISM \\
\hline
\end{tabular}}

General editor: Andrew S. Thompson

Founding editor: John M. MacKenzie

When the 'Studies in Imperialism' series was founded

by Professor John M. MacKenzie more than thirty years ago, emphasis was laid upon the conviction that 'imperialism as a cultural phenomenon had as significant an effect on the dominant as on the subordinate societies'. With well over a hundred titles now published, this remains the prime concern of the series. Crossdisciplinary work has indeed appeared covering the full spectrum of cultural phenomena, as well as examining aspects of gender and sex, frontiers and law, science and the environment, language and literature, migration and patriotic societies, and much else. Moreover, the series has always wished to present comparative work on European and American imperialism, and particularly welcomes the submission of books in these areas. The fascination with imperialism, in all its aspects, shows no sign of abating, and this series will continue to lead the way in encouraging the widest possible range of studies in the field. 'Studies in Imperialism' is fully organic in its development, always seeking to be at the cutting edge, responding to the latest interests of scholars and the needs of this ever-expanding area of scholarship.

\section{Imperium of the soul}

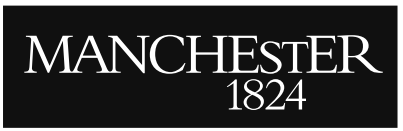

Manchester University Press 


\section{SELECTED TITLES AVAILABLE IN THE SERIES}

WRITING IMPERIAL HISTORIES

ed. Andrew S. Thompson

EMPIRE OF SCHOLARS

Tamson Pietsch

HISTORY, HERITAGE AND COLONIALISM

Kynan Gentry

COUNTRY HOUSES AND THE BRITISH EMPIRE

Stephanie Barczewski

THE RELIC STATE

Pamila Gupta

WE ARE NO LONGER IN FRANCE

Allison Drew

THE SUPPRESSION OF THE ATLANTIC SLAVE TRADE

ed. Robert Burroughs and Richard Huzzey

HEROIC IMPERIALISTS IN AFRICA

Berny Sèbe 


\section{Imperium of the soul}

\section{THE POLITICAL AND AESTHETIC IMAGINATION OF EDWARDIAN IMPERIALISTS}

Norman Etherington 


\section{Copyright (C) Norman Etherington 2017}

The right of Norman Etherington to be identified as the author of this work has been asserted by him in accordance with the Copyright, Designs and Patents Act 1988.

Published by Manchester University Press

Altrincham Street, Manchester M1 7JA

www.manchesteruniversitypress.co.uk

British Library Cataloguing-in-Publication Data

A catalogue record for this book is available from the British Library

Library of Congress Cataloging-in-Publication Data applied for

ISBN 9781526106056 hardback

First published 2017

The publisher has no responsibility for the persistence or accuracy of URLs for any external or third-party internet websites referred to in this book, and does not guarantee that any content on such websites is, or will remain, accurate or appropriate.

Typeset by Out of House Publishing

Printed in Great Britain

by TJ International Ltd, Padstow 